\title{
The sacred in museums, the museology of the
} sacred - the spirituality of indigenous people

Lo sagrado en el museo, la museología de lo sagrado - la espiritualidad indígena

\section{Marília Xavier Cury}

\section{OpenEdition}

Journals

\section{Electronic version}

URL: http://journals.openedition.org/iss/1529

DOI: $10.4000 /$ iss. 1529

ISSN: 2306-4161

Publisher

ICOM - International Council of Museums

\section{Printed version}

Date of publication: 12 October 2019

Number of pages: 89-104

ISBN: 978-92-9012-467-2

ISSN: 2309-1290

Electronic reference

Marilia Xavier Cury, "The sacred in museums, the museology of the sacred - the spirituality of indigenous people », ICOFOM Study Series [Online], 47(1-2) | 2019, Online since 12 October 2019, connection on 24 October 2019. URL : http://journals.openedition.org/iss/1529; DOI : 10.4000/iss. 1529 


\section{The sacred in museums, the museology of the spirituality of indigenous people}

\section{Marília Xavier Cury}

Museum of Archeology and Ethnology, University of São Paulo (MAE-USP) - São Paulo, Brazil

The great spirits are everywhere taking care of the Guarani people, observing their acts on Earth, judging their behavior and ensuring that the bad spirits do not take hold of their souls. At every place, at every moment, a spirit guides the steps of each and every human being. The spirits are present in each human being that surrounds us, they are in the plants, in the waters, in the sun rays, in the rain, everywhere. That is why we say everything is sacred. Even the soil makes part of our sacred world.

Workshop of Guarani teachers. The four sacred chants 
Different biases can be adopted to discuss the sacred in museums. This article is about the spirituality of indigenous people and how it affects work at museums, particularly curatorship. The arguments put forth here are grounded in collaborative initiatives and in the discourse and knowledge of indigenous people in Brazil. We claim that museums are sacred places because the objects of indigenous people are sacred, and the sacred is part of the lives of indigenous people. The musealized objects of indigenous peoples carry with them the energies of those peoples' ancestors, and evoke instances of communication with the spirits. It is a view that places the "enchanted" as museum curators, which requires new learning for new museum situations.

Key words: Museology and the sacred, Spirituality of indigenous people, Curatorship and the sacred, Collaborative process.

REsumen

\section{Lo sagrado en el museo, la museología de lo sagrado - la espiritua- lidad indígena}

La discusión de lo sagrado en el museo puede tomarse por diferentes retos. En el artículo presentamos la espiritualidad indígena y cómo influye el trabajo en el museo, especialmente de la curaduría. Los argumentos se mantienen en acciones de colaboración y en los conocimientos indígenas en Brasil. Mantenemos que los museos son lugares sagrados, porque los objetos indígenas son sagrados y la parte sagrada hace parte de la vida de los pueblos indígenas. Los objetos musealizados indígenas sí mismo transportan las energías ancestrales, mientras evocan comunicación con los espíritus. Es una visión que pone los espíritos como curadores del museo, lo que requiere nuevos aprendizajes para nuevas situaciones museológicas.

Palabras claves: Museología y lo sagrado, Espiritualida indígena, Curadoria y lo sagrado, Proceso colaborativo.

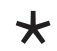

\section{Introduction}

There are many ways of understanding culture and museum audiences, and the cultural users of museums. Demand for museums can fit into categories such 
as age group, education, income, gender, skin color and race. Each of these categories can reveal aspects of the visitor profile, such as preferences, habits, views and conceptions, inclusions and exclusions, etc. Religiousness has been little explored in general, but here we consider it to be of key importance for discussing the sacred in museums and how museology must be framed to fit into the new paradigms. In Brazil, the focus of our reflections, a recent survey conducted in I2 cities offers us some indicators. The survey on frequency showed that $56 \%$ of people reported a high level of interest in museums, $32 \% \mathrm{had}$ a medium level of interest and I $2 \%$ of respondents had a low level of interest. Overall, the cinema came first with $69 \%$ of interest, music shows were second with $64 \%$ and theater was third at 58\%. (Leiva, Meirelles, 20I8, p. 33 ).

The survey also showed a known piece of information, namely that visiting museums is linked to a high education level (Bourdieu, 2003). According to the survey, $17 \%$ of museum attendees have nine years of schooling, while $57 \%$ of attendees have a university degree. The exclusive access to museums is shown by the fact that $58 \%$ of people with primary and junior secondary education are absent from museums, while only пा\% of people with university degrees do not visit museums (Leiva, Meirelles, 20I8, p. 37). This makes it clear that, if schooling is important, museums design their activities assuming a certain education level and therefore making exclusions. Income levels also determine museum attendance: lower income is associated with less museum use (Leiva, Meirelles, 20I8, p. 45).

Motivation, access, interest and encouragement - social and demographic factors not considered here - also play a role in determining museum use; however, discussions of these factors may adopt different biases. Religiousness is the factor we focus on, because it is closely linked to Brazil's multicultural and multiethnic society. Although Catholicism has played a leading role in shaping our culture, it has also been used to hide our religious diversity. Several religions have often been discriminated against and persecuted, particularly Afro-Brazilian religions. However, self-identification of religious affiliation depends on several factors, especially social and demographic factors that create a complex problem not yet considered by museology. In fact, a social and demographic analysis of religion remains to be done. This is a concern, as Brazil is susceptible to religion and the prejudices related to it.

Why is that a matter of concern to us? "It is important to acknowledge that religion is not strong enough to neutralize the influences of income and education levels on cultural habits" (Novais, 2018, p. 89). However, Catholicism still plays a leading role in Brazil, causing many museums to formulate subjective discourses under its influence.

We focus here on interpretations by museum visitors. Considering that attendees have access to museums for social and demographic reasons, they interpret what they see according to their cultural backgrounds, and religion may play a role in that. It is what Jesus Martín-Barbero (1997) calls cultural 
mediations, shifting the focus of communication from the media (museums, exhibitions, the issuance and transmission of messages) to the contexts of where and how meanings are built.

The aspect that draws our attention regarding the religiousness of museum visitors is the cultural mediation required to establish museum communication as part of curatorship activities. Mediation, as a locus from which audiences make interpretations, creates meaning and significations as a component of producing museum content. For museum communication purposes, mediation is "the dynamics of building these contents, the use and appropriation of these contents and the wording of these contents" (Lopes, 20I4, p. 66). Moreover, mediation is a "framing process that shapes and reshapes both the interaction of audience members, the media and the audience members' creation of the meaning of such interaction" (Lopes, 20I4, p. 7I).

In Brazil, the hegemony of Catholicism has been changing over the years due to the surge in religious diversity. Evangelical churches have increased in number, and the presence of these churches in the cultural scenario has also increased as meeting places for the young, in mass communication, through television network concessions and in politics at the federal, state and municipal levels (Novais, 2018).

Most visitors to museums in capital cities (Leiva, Meirelles, 20I8, p. 83) follow spiritism (44\%) and Afro-Brazilian religions (46\%). This fact calls for attention because these religions deal with spirituality; thus, we choose to consider the spirituality of indigenous people to discuss the sacred in museums and the museology of the sacred. The statistics show us that people identifying with spiritual religions are the most interested in museums, an observation that social and demographic factors may not be able to fully explain. What we see, in the representations of these audiences, about indigenous people is the possibility of a dialogue through a shared spirituality, an exchange of "interpretations, a dialogical practice that can cause surprise and estrangement, but can ultimately lead to a merge of horizons" (Pacheco de Oliveira \& Santos, 20i6, p. 20) between indigenous and non-indigenous people. Museum communication and its contribution to museology come in at this point.

The reflections offered in this article originate from research carried out at the University of São Paulo's Museum of Archeology and Ethnology (MAEUSP). They address the transformations that ethnographic museums currently undergo, particularly after the criticism made to academic knowledge whereby ethno-museology, new museology and eco-museums come together to add new practices to museum procedures. That causes the museum field to decentralize, diversify and expand, and to rely on participation and sustainability to carry out its activities.

An ethnographic museum is a strategic site for indigenous peoples, because it acts as a political space, preserves the objects of ancestors, allows interge- 
nerational initiatives about tradition and ancestry to take place, and is also a place of speaking and visibility that indigenous people need to build respect.

Collaboration allows joint work between museums and cultural groups for intercultural purposes - confluence, interaction, reciprocity and active close relationship - providing a method for different cultural beings to negotiate. Collaboration is an attitude that fosters full reciprocity when players carry out actions, such as the study of collections and development of exhibitions. In these experiences, both museum and indigenous peoples benefit by sharing their purposes: the museums have the "stuff" to exhibit and "it is the tribal communities that hold the real content that is necessary for accurate and appropriate interpretation." Indigenous peoples have the histories, perspectives and "understandings that can transform a collection of objects into meaningful inter- (native to non-native) and intra- (within native communities)" cultural experiences" (Hoerig, 20I0, p. 65). Therefore, in an ethnographic museum involved in a collaborative initiative, these communities act as curators through their participation in producing the knowledge that is inserted in the museum.

Collaborative initiatives, even in an isolated and partial manner, are responses to decades of criticism from indigenous people about how they are depicted by ethnographic museums and how these museums formed their collections, among other issues involving the colonization of their cultures and heritage. One issue that most troubles indigenous peoples centres on things that are sacred to them, particularly ritual objects and shaman objects, but also related to the dead and their cemeteries and burial sites.

Ethnographic museums are indebted to indigenous peoples, and collaboration may be a strategy to make attitudes to decolonize museums explicit, thus revealing the logic of coloniality. According to Fred Wilson's Mining the Museums (1992):

\section{[...] movement towards the decoloniality of the being and of the knowledge which, on one hand reveals the underlying assumptions of the institution itself, and on the other hand uses the institution to reveal what was hidden under the colonial histories about slavery and the consequences of racism. An act of epistemological and aes- thetic disobedience in the best possible style" (Mignolo, 2018, page} 318).

The purpose of this article is to bring to light, from the viewpoint of museology, the indigenous view about spirituality in order to foster change in the attitude towards ancestral objects, traditional cultures and indigenous spiritual leaders. The arguments put forth here are grounded in dialogue with indigenous peoples through a collaboration; this initiative proposes the decolonization 
of museums, using multiple visions and viewpoints, while at the same time proposing other approaches to the visiting public, encouraged by spirituality.

\section{Museology and counter-hegemony}

A hegemonic approach has been associated with museums since the building of nation states and national identities; museums have been used to realize these ideals in Europe and America.

Post-modernity has produced effects on human relationships and a change in the conception of culture: "interrelationships in global contexts, dispersion, fluidity and fragmentation of identities, merging and hybridization of ethnic barriers, deterritorialization of cultures, etc." (Barona Tovar, 20i6, p. 59). If that perspective has caused changes in anthropology, we can say the same applies to museology and museums, which start to consider "us", otherness and reconstructions of identities. As a result, we work from the viewpoint of the cultural diversity of indigenous peoples in order to understand the distinguishing features of our time. Curators of ethnographic museums start to become intercultural subjects who share common places (Barona Tovar, 20I6, p. 6I) with indigenous groups, and museums become multicultural sites in this democratic practice.

What is the raison d'être of museums in a world where identities are fragmented, relational and partial? It is at the institution's point of inflexion to understand our time. Therefore, the purpose of a museum is to:

[...] facilitate the recognition of other realities represented in the worlds of indigenous peoples, Black people, peasants and city dwellers, by suggesting visitors to participate in the reflection about their rituals, symbolisms and thinking, not as a distant reality, rather something that happens in an exotic manner, worthy of being observed as such; otherwise it makes up part of our daily lives, our shared geographies, our definitely intercultural realities (p. 68).

Despite breakthroughs in social sciences and humanities that have supported changes in anthropology and museology, other forces have an influence on museums and maintain hegemonies. Pacheco de Oliveira and Santos (2016, p. I8) discuss the "museum illusion" that consists of decontextualizing collections built in the past, disregarding the origins of their formation, causing objects to become detached esthetic artifacts in art museums, involving other issues such as art-collecting markets and mass tourism. Accordingly, there is no "possibility of discussing the contemporaneity of the political communities that have created those objects". For Price (2016, p. 277), supported by Michel-Rolph Trouillot, "hygienizing" objects consists of removing or changing the informa- 
tion that accompanies them. That "hygienization" also affects the original meaning of objects on display to favor an esthetic presentation for contemplation purposes (p. 280). "Hygienization" works to silence the voice of history, causing an erasure of narratives and personalities. On the contrary, museums should reveal what is hidden, amplify voices and expand visions, approximate those who are different and close the gaps between differences, as well as promote themselves as sites of complex traditional knowledge, knowledge that used to be displayed in museums in the third person: "they". Therefore, museums should offer indigenous peoples the opportunity to play leading cultural roles and to represent themselves.

Diversity, differences and inclusion are part of museology's achievements, which include the opening of museum spaces

for people to live together building socially and politically valid relations, within the minimum common grounds of a democratic system that rests on intercultural relations (Barona Tovar, 2016, p. 61).

Therefore, musealization overthrows the particularization about the cultural "other", specifically here indigenous people, to approximate the realities of the researcher and of the research subject, in this case the indigenous peoples of Brazil, to share common places (Barona Tovar, 20i6, p. 6I).

Among the hegemonies and the new paradigms for museums, collaborative processes end up establishing new relations (Roca, 2015b), breaking apart the relationships between the researcher and the research subject and between curatorship and the represented entity, causing a rethinking of the participation of indigenous people in museum and exhibition activities, so that they have control over the political effects of exhibitions. In line with such political action, feelings and pieces of information would reach the museum's visitors, fostering complicity and leading to questions and inquiries (Pacheco de Oliveira \& Santos, 2016, pp. 20-2I).

Close relations between museums and indigenous peoples through collaboration are not recent. One example to highlight is the Portland Museum of Art, Oregon, where the Tlingit worked with ancestral objects, and therefore raised contemporary issues for the group (Clifford, 1997). The Museum of Anthropology (MOA) of the University of British Columbia in Vancouver started to work together with the First Nations in the late ig8os, and such work is still ongoing (Roca, 2015a, Roca, 2015b). In that museum, the pioneer of consultation initiatives with the First Nations was Michael McClean Ames.

In Brazil, collaboration occurs in some institutions, namely: Museu do Indio, Rio de Janeiro; MAE-USP; Museu Paraense Emilio Goeldi, Pará; the Federal University of Santa Catarina's Museum of Archeology and Ethnology; and the 
Federal University of Paranás Museum of Archeology and Ethnology. There are fewer experiences with respect to spirituality, but some practices with Afro-Brazilian groups at the Museu do Homem do Nordeste in Recife, state of Pernambuco, have been reported (Silva, 1992).

The theme of the sacred favors the contemporary debate about hegemony and counter-hegemony in museums and in museology, and to that end we refer to the spirituality of indigenous people. In the current case, we defend the desacralization of museums (Cury, 2016, 2017a, 2018).

The thoughts presented originate from collaborative research initiated in 2010 in the West of São Paulo, Brazil, with Kaingang, Terena and Guarani Nhandewa groups of the Araribá, Icatu and Vanuíre indigenous lands. It offers an experience of disrupting museum logic by incorporating indigenous peoples' knowledge into museum thinking and procedures. Within the framework of collaborative research aimed at indigenizing museums (Roca, 2015a), indigenous people play a leading role in discussions through their discourses, arguments and knowledge. Several research initiatives were carried out with these groups in their indigenous lands, at Museu India Vanuíre and at MAE-USP. Between 2016 and 20I8, we jointly organized the exhibition called Resistência Já! Fortalecimento e União das Culturas Indígenas Kaingang, Guarani Nhandewa and Terena (Resistance Now! Strengthening and Uniting Indigenous Cultures - Kaingang, Guarani Nhandewa and Terena). This collaboration resulted from the collections displayed in their local region by the Geographical and Geological Commission of the State of São Paulo (1905 and 1907) and by anthropologists Herbert Baldus, Harald Schultz and Egon Schaden (1947). One stage of the initiative was the requalification of collections (July 2017), where indigenous peoples had the opportunity to be with the objects. Fieldwork also fostered collaboration; close working relationships allowed mutual trust to build and better access to knowledge. Knowledge of spirituality was the most difficult to access, and to that end building trust was essential.

\section{Spirituality from an indigenous viewpoint}

At the beginning of the research, it was curious to note the appropriations made by Pajé (Brazilian shaman responsible for indigenous rituals to invoke and communicate with spirits) Jorge Garcia, Kaingang of the indigenous land of Nonoaí, in the Brazilian state of Rio Grande do Sul, at Museu India Vanuíre in Tupã, in the Brazilian state of São Paulo: lectures, explanations and demonstrations about mythical heroes, about the healing power of herbs, communication with the supernatural, dancing presentations and an indigenous baptism at the site of the Bravos Kaingang Tahap! exhibition (Cury, 2016).

In 2015, something happened during a lecture at the First Forum of the Indigenous People Museums of Ceará and First Forum of the Indigenous People Museums of Brazil on May I6-I7, organized by the Museu Indígena Kanindé (Kaninde Indigenous People Museum). The theme - Indigenous People Museums 
and Social Museology in a contemporary context: challenges for the indigenous peoples' management of museum activities - was presented to an audience of indigenous peoples, many of them caciques (chiefs) and shamans. The presentation was prepared throughout the day after listening to indigenous peoples' expectations about museums. One point seemed relevant: the connection between the past, the present and the future and the importance of ancestry. During the subsequent discussion, Pajé Babosa, a shaman of the Pitaguary people of Ceará, possessed by an ancient spirit, assumed the role of the "enchanted" and said, while sitting next to the lecturer (myself): "The past is always ahead of the present." The manifestation of this supernatural being was witnessed by audience members, who explained later that the materialization was a special tribute to the lecturer: the "enchanted" had chosen that moment and the lecture to manifest themselves. We then realized the strength of what we do and say and the greatness of the shamans.

When working with Kaingang José da Silva Barbosa de Campos, before entering into the forest with me, he always asked his ancestors for permission and explained to them why we were there. With respect to spirituality, he explained that the ancestors are part of the daily lives of indigenous people.

We talk with several people. The thought comes in a flash and has to be voiced at that moment. Everything comes from the people that have already left and are together with us in spirit [...]. It is as if my grandmother were speaking now. (Campos, 2016, p. 61)

Pajé (Kujã) Kaingang Dirce Jorge Lipu Pereira talks about her ancestors:

- Now the people at our settlement [indigenous land of Vanuire] respect each other a lot, because when we talk about culture we are talking about them. Whenever we remember culture, anything, what do we remember? We are talking about our ancestors. And we remember them every day. And we already learn about that inside the family, because our families, our mothers, our fathers are the teachers who are teaching us since we are born, since we are children, they are teaching us about our people, our culture and our spirituality, which are all connected. Therefore, there is no separation. This is because when you talk about culture you go backwards. You will always be going a long time back

For Dirce, her ancestors are always present in her memories, in her learning, and in her daily life. But ancestors are also present in a spiritual manner.

Francilene, a member of the Pitaguary people of Ceará, argued that spirituality should be taught at universities with the support of scholars: 
- That's it: we are the ones who have a broad view of spirituality. Many people think that doesn't exist, but that is what moves us. It is our spirituality, our chants, our respect for our ancestors.

What these three indigenous people show us is their connection with their forebears and how this connection is in their daily lives and their culture. They also talk about the presence of, and communication with, spirits. Death is physical for them, but the spirits keep playing a role in the daily lives and culture of the people.

It is this mystical universe of which the museum is unaware. Some issues trouble indigenous people deeply, such as how museums deal with human remains and research conducted in cemeteries. With respect to these issues, conversations with indigenous persons are transcribed in their original form, because they must be preserved during discussions.

\section{Museums, human remains - ancestry and respect}

Kaingang Dirce voiced her opinion when asked about research on human remains in museums.

- About the research conducted on our human remains, what we ask is that those researchers who come to study our ancestors should bear in mind that they do not consist only of bones. They are human beings. They are people. Our ancestors have suffered a lot already and deserve our respect.

Dirce Jorge and other indigenous people know how museums are organized, their areas and activities, and the arrangements made at museums. She lives with, works at, and collaborates with museums. Because she knows museums, she can guide museum researchers and professionals so that they respect indigenous peoples' ancestors; she can guide curators on how to store objects and remains, including how to give physical care, and also on how to place the sacred objects of other cultures.

- So that is what we ask for to all those that make research in museology. That's it. That's the way it is. How could they remove the body from the place where it was buried? Nobody asked for permission to take the dead from their burial sites! These people were there, removed the bodies from their graves and put them [in museums]. In order not to leave them anywhere, there should be a special place to put the human remains [in the museum], a special place should be set aside for them. These human remains [should] not be taken by any person. Let the human remains go this way, go that way. No. Things should be done with a lot of respect. I say what I have learned at home. We also learn because we have our own culture.

And she proceeded to talk about spirituality, reminding the audience that human remains are living entities. 
- All that we ask from you when you handle our relatives, our ancestors, is the following: Talk to them. Speak with them: "Excuse me, I am handling you because this is what I study." So that's it. That's what we ask for.

\section{Indigenous people cemeteries - feelings and indignation}

The relationship of indigenous people with natural sites is intense, because these are places where fights, deaths, rituals, births have taken place, where the dead have been buried, where their ancestors lived. Forests are sacred, and entering them requires permission. Little (2012, p. 396) points out that archeological sites and exhibitions appeal to their spirituality. Descendants recognize sites and objects related to their ancestors.

Among archeological sites, indigenous people cemeteries stand out for their sacredness, but also for the extent to which the remains of indigenous people are manipulated. Cristine Takuá, a Maxakali living in São Paulo, raises the issue, drawing comparisons to convince her audience.

- All these reflections have to be made, because I see that the cemeteries of non-indigenous people have small houses, small castles are placed on top of their dear ones. And now there are many cities built over indigenous people cemeteries. And there is no respect for them.

Steadfast in her arguments and reasoning, she challenges the researcher:

- Once I asked an archeology researcher the following: «Would you like to unearth your grandmother, your mother and to study her in front of everybody?»

She answers the question herself, highlighting the suffering caused to indigenous people by archeological research.

- Never! No researcher would exhume his or her mother. So, why indigenous peoples have to cope with the pain and suffering of seeing a relative even if they are not close? Particularly the shamans, who are so sacred, who heal people. When a shaman is buried, a great spiritual force is with them!

Besides the inability to deal with the feelings of others, there is also a lack of spiritual and emotional preparation.

- And then researchers are unearthing these things with no preparation, no care, no respect at all. My intention was only to put forth these reflections, I believe that you should think about that, but I have said all this only to enliven more our thoughts!

Susilene Elias de Melo, assistant of Pajé (Kujã) Dirce Jorge, a member of the Kaingang people, who was raised in this spirituality and attends to all rituals and procedures, faced the researcher questioning her.

- If you are so curious to know what happened, I am also curious! What did they die of? Were they poisoned? How did they die? What was it? Was it a gunshot? Was it a bullet? Was it beating? 
The questions were posed during the research, when the archeologist made the Kaingang his informer. When she inverted positions and asked him a question, she got no answer.

- And he couldn't answer me, he was unable to give me an answer.

Like Cristine Takuá, Susilene develops her reasoning.

- Then I told him: "Considering that you were unable to give me an answer, why meddle with it? Leave the remains where they are. Don't meddle with them!" He is a researcher, yet he couldn't say to me whether the dead was poisoned or what was the cause of death. For this reason, you don't have to meddle with the dead, leave them in their places.

Susilene reinforces the point made by Dirce Jorge about authorization.

Because actually they [researchers] don't ask for permission. Allow people to manipulate your remains?! Would you like it? He was silent.

About the lack of preparation to deal with spirituality:

And I told him: "Leave it like that! Because you don't know whom you are meddling with!" As Cristine said: "You don't know if the dead was a shaman, you don't know the ritual followed for the burial, so leave them alone! Don't meddle with them!" That is what I had to say!

\section{The museum object - the sacred object at museums}

Pajé Babosa from the Pitaguary people of Ceará helps us understand why indigenous peoples' objects are sacred and remain sacred despite their musealization.

- I absorb the concerns about spirits that we bring from all places into the museum. This glass here that I have taken, it has my energy, and whoever takes it home will take me also. This is what sacredness is all about. If this glass here belonged to an ancestor it will carry the [ancestor's] energy.

Therefore, every indigenous object in the museum belongs to an ancestor or will belong to an ancestor after they leave this world. Musealization does not deprive indigenous objects of their nature, but we should acquire this knowledge when musealization takes place. This is not a matter of belief - what I believe or not believe - but of respecting indigenous knowledge.

Dirce Jorge Lipu Pereira gives us the following advice on museum objects:

- What I say to people who work at and who are at museums is that for us a museum is a sacred home. We always talk about respect, about showing respect to everything that you take: ask for permission. "If am going to pick up an object I say: Oh, excuse me! I am going to research you, I am going to see you, I am going to take hold of you." That's what we ask for then. Respect. That's what we ask for.

Susilene finishes her argument: 
- Many people say the following about indigenous human remains: «Ah, these people are dead already. Once buried everything is over." No, it is not over, they have only left their bodies, but they are there with us. The dead are permanently next to us, teaching us. They talk to us while we sleep. They come to teach us how to do craftwork, how to make necklaces, how to make earrings, and for this reason we craftspeople are connected with spirituality. All of us. Talking about culture connects everything. Everything is together, there's no way to separate things. That's it.

That's it! Museum objects carry the energies of ancestor craftspeople, and are also the result of the will of the "enchanted" who guide the hands of the craftspeople.

When we work with these objects in museums, according to indigenous teachings, we evoke the ancestors. Afraid of what to do and how to do it, the shamans said, the museum professionals take care of the objects, we heal them, and that gives a new meaning to curatorship: to heal, to take care (Cury, 2018, p. 62). Curing and curating lie at the origin of curatorship. What curatorship? What kind of care? The care we learn about in museology and museography classes, but also the care we learn from indigenous spirituality.

Again, it may be a matter of belief for some people, but what we reinforce here is a respectful attitude and a new ethical behavior in our relationships with indigenous people. Moreover, a new understanding about what curatorship is, as well as new professional commitments.

\section{Curatorship and curators - the presence of spirituality, the healer-enchanters}

After many years working with indigenous peoples, I should add that spirituality is part of the daily lives of museums.

When working with museum objects, museum professionals search for all references to them in order to describe their lives before and after musealization. We have appropriated their history.

Given the spiritual dimension of museums, we, both indigenous people and professionals, evoke the spiritual world, and for that reason we should know how to deal with the (new) situations. By adopting a respectful attitude, museum professionals meet the requirements of the spiritual world. Their curatorship will be based on attention to ancestry; after all, we know what that means; all of us have our ancestors, although not all of us show the same respect for them. We need this respect when dealing with objects from other cultures in museums; and for that reason, many times we must learn again everything that we have lost throughout our lives.

However, spirituality is revealed to shamans and their assistants, they feel what we do not: the presence, the emotions, the pain, the suffering, the joys, 
the worries. They receive supernatural messages consisting of guidance and requests - the order, as is sometimes mentioned.

When dealing with curatorship, professionals make choices about preventative conservation measures, restoration concepts, storage of objects in technical reserves, formulation of exhibition concepts, objects to be exposed, contents of texts and labels, etc. All I can say is that all these issues, and others, could have the participation of the "enchanted" through shamans or people susceptible to spirituality. Accordingly, supernatural beings are active participants in the process, they are curators as much as we are (Cury, 2016, 2017).

Spirituality is in the objects, spirits are invoked by us and by indigenous people, and they feel that other contributions and guidance are part of this process.

The sacredness of museums lies in this understanding, but also in their consecration by shamans (Carvalho, 20I5, Cury, 2016), who play a key role in cherishing indigenous traditions, something that should continue at museums. We owe the same respect to shamans inside and outside museums, for the spiritual leadership they exercise and because they carry on their shoulders the responsibility of preserving indigenous cultures through spirituality. Without spirituality, indigenous cultures lose much of what they are. Without the paradigm of spirituality, museums lose much of their complexity (Cury, 20r6).

Collaborative initiatives that rely on the direct participation of indigenous people should put the new actors back on the curatorship team again.

Indigenous people are curators of their collections and of the exhibitions they take part in, I have no doubts about that. However, the enchanted are curators as well, because they communicate with the physical world when evoked by the object, and with the feelings and thoughts of those who see the objects as part of themselves, things that comes from their ancestors. (Cury, 2017, p. 206)

9

If spirits are everywhere, they are also in museums. If everything is sacred, so are museums. And, as indigenous people say, paths will be open, but also illuminated. May museums be illuminated!

\section{References}

Barona Tovar, F. (2016). Museus, antropologia e identidades culturais em Colômbia. In M. Lima Filho, R. Abreu \& R. Athias (Orgs.). Museus e atores sociais: perspectivas antropológicas. (pp. 57-7I). Recife: ABA. 
Bourdieu, P. (2003). O amor pela arte: os museus de arte na Europa e seu público. São Paulo: EDUSP: Zouk.

Campos, J. S. B. (2016). Preservação da cultura Kaingang pelo conhecimento dos antepassados. In Povos indígenas e psicologia. A procura do bem viver. (pp. 58-63). São Paulo: Conselho Regional de Psicologia de São Paulo.

Carvalho, J. (2015). O museu, o nativo e a musealização do objeto. Campos, I6(2), 59-74.

Clifford, J. (I997). Museums as contact zone. In J. Clifford (Ed.), Routes: travel and translation in the late twentieth century. (pp. I88-219). Cambridge: Harvard University Press.

Cury, M. X. (2018). La museología y lo sagrado - La resacralización del museo. In F. Mairesse. (Ed.). Museology and the sacred. Materials for the discussion. (pp. 6o-64). Paris: ICOFOM.

Cury, M. X. (20I7a). Lições Indígenas para a descolonização dos Museus Processos comunicacionais em discussão. Cadernos Cimeac, 7(I), I84-2II. https://doi.org/I0.I8554/cimeac.v7ir.2199.

Cury, M. X. (20I7b). Circuitos museais para a visitação crítica: descolonização e protagonismo indígena. Ritur, 7, 87-II3. DOI: 10.2436/20.8070.01.65.

Cury, M. X. (20i6). Relações (possíveis) museus e indígenas - em discussão uma circunstância museal. In: M. Lima Filho, R. Abreu \& R. Athias (Orgs.). Museus e atores sociais: perspectivas antropológicas. (pp. I49-170). Recife: UFPE: ABA.

Cury, M. X. (20I5). Dimensão pública da arqueologia - contribuição dos museus. In P. P. A. Funari, J. B. Campos \& M. H. S. G. Rodrigues (Orgs.). Arqueologia Pública e o patrimônio: Questões atuais. (pp. 327-352). Criciúma: UNESC.

Hoerig, K. A. (2010). From third person to first: A call for reciprocity among non-native and native museums. Museum Anthropology, 33(I), 62-74.

Leiva, J., \& Meirelles, R. (2018). Cultura nas capitais: como 33 milhões de brasileiros consomem diversão e arte. Rio de Janeiro: I7Street Produção Editorial.

Little, B. J. (20I2). Public benefits of Public Archaeology. In R. Skeates \& C. McDavid (Eds.), The Oxford handbook of Public Archaeology. (pp. 395-4I3). Oxford: Oxford University Press.

Lopes, I. (20I4). Mediação e recepção. Algumas conexões teóricas e metodológicas nos estudos latino-americanos de comunicação. Matrizes, 8(I), 65-80.

Martín-Barbero, J. (I997). Dos meios às mediações: comunicação, cultura e hegemonia. Rio de Janeiro: Editora UFRJ. 
Mignolo, W. (2018). Museus no horizonte colonial da modernidade. Garimpando o museu (1992) de Fred Wilson. Museologia \& Interdisciplinaridade, 7(13), 309-324.

Novais, R. (2018). Hábitos culturais. A religião importa? In J. Leiva \& R. Meirelles. Cultura nas capitais: como 33 milhões de brasileiros consomem diversão e arte. (p. 87-89). Rio de Janeiro: 17 Street Produção Editorial.

Pacheco de Oliveira, J., \& Santos, R. C. (2016). Descolonizando a ilusão museal - etnografia de uma proposta expositiva. In M. Lima Filho, R. Abreu \& R. Athias (Orgs.). Museus e atores sociais: perspectivas antropológicas. (pp. I7-58). Recife: UFPE: ABA.

Pereira, D. J. L. (2016). Resistência e defesa da cultura Kaingang. In Povos indígenas e psicologia. A procura do bem viver. (pp.53-57). São Paulo: Conselho Regional de Psicologia de São Paulo.

Price, S. (2016). Higienização da cultura poder e produção de exposição. In M. Lima Filho, R. Abreu \& R. Athias (Orgs.). Museus e atores sociais: perspectivas antropológicas. (pp. 273-283). Recife: UFPE: ABA.

Roca, A. (2015a). Acerca dos processos de indigenização dos museus: uma análise comparativa. Mana, 2I(I), I23-155.

Roca, A. (20I5b). Museus indígenas na Costa Noroeste do Canadá e nos Estados Unidos: colaboração, colecionamento e autorrepresentação. Revista de Antropologia, 58, II7-I42.

Silva, M. R. B. (1992). O processo de comunicação como fato cultural no Museu do Homem do Nordeste. Ciências e Museus, 4, 63-65. 